\title{
Effects Of A. Congensis Extract On Heamatology Of Albino Rat
}

\author{
S. N. Nmezi, M. O. Nwachukwu, M. C. Igbomezie
}

\section{ABSTRACT}

Purpose: The study was conducted to investigate the possible effects of Alstonia congensis (leaf, bark and root) extracts on heamatology of albino rat.

Is the extract poisonous? What is the ${ }^{2} D_{50}$ of the extract? Is the heamatology of the test animals affected by the extract? Is the effect dangerous for the animal?

\begin{abstract}
Method: The study was carried out between February 2019 to October 2020. A. congensis was collected from Emekuku area of Imo State. The albino rats were purchased from the Animal Science and Production Department of Michael Okpara University of Agriculture, Umudike, Umuahia. Acute toxicity studies of the crude extracts were carried out in albino mice. The possible effects of the extracts on hematology of the albino rats were determined using automated machine.
\end{abstract}

Results: In acute toxicity test, all the mice that received the doses $(10$, $100,1000,1600,2900$ and $5000 \mathrm{mg} / \mathrm{kg}$ ) of the extract survived beyond the 2weeks of observation. The medium lethal dose toxicity value $\left(L_{50}\right)$ of the extract must be above $5000 \mathrm{mg} / \mathrm{kg}$ which indicates that the extract is safe for consumption. The extracts did exhibit some hematological changes, the packed cell volume (PCV) of the test animals were reduced. The RBC of the animals were reduced significantly when $800 \mathrm{mg} / \mathrm{kg}$ of bark extract was given, but no mortality was observed. The $\mathrm{WBC}$ and $\mathrm{HB}$ of the animals were affected but the effects were not significant. There was no evidence of druginduced symptoms at all the doses of the extract administered.

Conclusion: The extract can be deleterious to the heamatological parameters of the test animal when used in high doses for a long period. Therefore, it is advisable to be used in chronic cases where orthodox medicine failed.

Keywords: Alstonia, dose, extract, haematology, toxicity.
Submitted: September 28, 2021

Published: February 18, 2022

ISSN: $2593-8339$

DOI: $10.24018 /$ ejmed.2022.4.1.1083

\section{S. N. Nmezi*}

Department of Biology, Federal University of Technology Owerri Imo State, Nigeria.

(e-mail: nmezistella19@gmail.com)

M. O. Nwachukwu

Department of Biology, Federal

University of Technology Owerri Imo

State, Nigeria.

(e-mail:

nwachukwumichaelo@yahoo.com)

M. C. Igbomezie

Department of Chemistry, Federal University of Technology Owerri Imo State, Nigeria.

(e-mail:

igbomeziemaryann29th@gmail.com)

*Corresponding Author

\section{INTRODUCTION}

Phytotherapeutic agents or phytomedicines are standardized herbal preparations consisting of complex mixture of one or more plants which are used in most countries for the management of various diseases. Usually, the active principles responsible for their pharmacological action are unknown. One basic characteristic of phototherapeutic agents is the fact that they normally do not possess an immediate or strong pharmacological action [1]. For this reason, phototherapeutic agents are not used for emergency treatment. Other characteristics of herbal medicine are their wide therapeutic use and great acceptance by the population. In contrast to modern medicines herbal medicines are frequently used to treat chronic diseases. Subacute toxicity evaluations are required to establish potential adverse effects of the medicinal preparations on internal organs [2]. A complete blood count (CBC), also known as a complete blood cell count, full blood count (FBC), or full blood exam (FBE), is a blood panel requested that gives information about the cell in the blood, such as the cell count for each cell type and the concentrations of various proteins and minerals. Blood counts of various types have been used for clinical purposes since the 19th century. Automated equipment to carry out complete blood counts was developed in the 1950s and 1960s [3].

The cells that circulate in the bloodstream are generally divided into three types: white blood cells leukocytes red blood cells (erythrocytes) and platelets (thrombocytes). Abnormally high or low counts may indicate the presence of many forms of disease. According to work carried out by [4], on Malaria anemia of mice and man, hematological abnormalities are considered a hallmark of malaria. Reference [5] reported that $P$. berghei increases erythrocyte fragility and significantly reduces PCV in rat and also affects the WBC which is an important index of pathological and physiological status [6]. 


\section{MAterials AND MethodS}

\section{A. Extraction of Plant Materials}

Fifty grams $(50 \mathrm{~g})$ of the pounded dried plant materials (leaf, bark and root powder) were weighed and extracted with $400 \mathrm{ml}$ of aqueous (distilled water) and $400 \mathrm{ml}$ of ethanol using [7], extraction method. The processes were run for 2 hours each after which the samples were evaporated to dryness using water bath. The dried extracts were weighed and kept in a well labeled sterile specimen bottles and stored in are refrigerator at $4{ }^{\circ} \mathrm{C}$ until is required.

\section{B. Acute Toxicity/Lethal Dose (LD50) Test}

The medium lethal dose of the crude extracts of leaf, bark and root of $A$. congensis were determined by [8] method using the oral routes with the assistance of Pharmacist Solomon Nwafuru of Federal Medical Centre, Owerri. The acute oral toxicity study was conducted in compliance with OECD guideline 425 , which stipulate the use of only three animals [9]. The test was divided into two stages.

Stage One: Determination of the toxic range of the leaf, bark and root extracts of Alstonia congensis. Albino rats were divided into 9 groups of 3 animals in each group. Each group received a dose $(10,100,1000 \mathrm{mg} / \mathrm{kg})$ of the ethanolic extracts of leaf, bark and root suspended in distilled water respectively. The doses were administered orally, and the treated animals observed for 72 hours for number of deaths.

Stage Two: Determination of lethality of leaf, bark and root extracts. The doses used in this stage were determined from the number of deaths per dose recorded in the stage one test. Since no death occurred in the stage one test, three different higher doses: $1600 \mathrm{mg} / \mathrm{kg}, 2900 \mathrm{mg} / \mathrm{kg}$ and 5000 $\mathrm{mg} / \mathrm{kg}$ were administered to another group of animals at one dose per animal. The treated animals were monitored for number of deaths for 24 hours and continued to 72 hours. The $\mathrm{LD}_{50}$ in this test is determined by calculating the geometric mean of the test and most toxic doses.

\section{$\mathrm{LD}_{50}=\sqrt{\text { minimum toxic dosexmaximum tolerated dose }}$}

\section{Sub-Acute Toxicity Studies}

For the sub-acute toxicity studies, hematological parameters were determined in relation to the control treatment. These include packed cell volume (PCV), white blood cells (WBC), red blood count (RBC), haemoglobin (HB), platelets, etc. These investigations were carried out to determine the effect of the extract on internal organs using albino rat as the test animals. A low (400 mg/kg) and high $800 \mathrm{mg} / \mathrm{kg}$ of the extracts were used in this study.

\section{Data Analysis}

Data were analyzed using computer software SPSS, Version 16. Results of the study were expressed as a mean \pm standard error of the mean ( $\mathrm{m} \pm \mathrm{SEM})$. Statistical significance was determined by one way analysis of variance (ANOVA) with multiple comparison tests (Post Hoc/Tukeys test/HSD) to compare parameters within groups. All data were analyzed at a $95 \%$ confidence interval $($ alpha $=0.05)$.

\section{RESULTS}

\section{A. Pre-Treatment Acute Toxicity/Lethality Test}

The result of the lethality and acute toxicity studies of the leaf, bark and root extract of Alstonia congensis in a naïve rat are shown below.

TABLE I: ACUTE TOXICITY $\left(\mathrm{LD}_{50}\right)$ TEST OF THE CRUDE LEAF EXTRACT OF $A$. congensis

\begin{tabular}{ccc}
\hline \hline Stages & Doses $\mathrm{mg} / \mathrm{kg}$ & Mortality \\
\hline \hline \multirow{2}{*}{ Stages 1 } & 10 & $0 / 3$ \\
& 100 & $0 / 3$ \\
& 1000 & $0 / 3$ \\
Stages 2 & 1600 & $0 / 1$ \\
& 2900 & $0 / 1$ \\
\hline \hline
\end{tabular}

TABLE II: ACUTE TOXICITY (LD ${ }_{50}$ ) TEST OF THE CRUDE LEAF EXTRACT OF $A$. congensis

\begin{tabular}{ccc}
\hline \hline Stages & Doses $\mathrm{mg} / \mathrm{kg}$ & Mortality \\
\hline \hline & 10 & $0 / 3$ \\
Stages 1 & 100 & $0 / 3$ \\
& 1000 & $0 / 3$ \\
Stages 2 & 1600 & $0 / 1$ \\
& 2900 & $0 / 1$ \\
& 5000 & $0 / 1$ \\
\hline \hline
\end{tabular}

TABLE III: ACUTE TOXICITY (LD ${ }_{50}$ ) TEST OF THE CRUDE LEAF EXTRACT OF $A$. congensis

\begin{tabular}{ccc}
\hline \hline Stages & Doses $\mathrm{mg} / \mathrm{kg}$ & Mortality \\
\hline \hline & 10 & $0 / 3$ \\
Stages 1 & 100 & $0 / 3$ \\
& 1000 & $0 / 3$ \\
Stages 2 & 1600 & $0 / 1$ \\
& 2900 & $0 / 1$ \\
& 5000 & $0 / 1$ \\
\hline \hline
\end{tabular}

TABLE IV: SHOWING THE EFFECT OF THE EXTRACTS OF $A$. congensis PARTS ON THE HAEMATOLOGICAL WBC AND HB OF TEST ANIMALS

\begin{tabular}{cccc}
\hline \hline Parameters & Treatment & Mean values & Significance \\
\hline \hline WBC & Normal (control) & $19.42 \pm 2.83$ & - \\
& $400 \mathrm{mg} / \mathrm{kg} \mathrm{Leaf}$ & $24.42 \pm 4.87$ & $\mathrm{P}>0.05$ \\
& $800 \mathrm{mg} / \mathrm{kg}$ Leaf & $19.13 \pm 4.18$ & $\mathrm{P}>0.05$ \\
& $400 \mathrm{mg} / \mathrm{kg}$ Bark & $19.83 \pm 2.58$ & $\mathrm{P}>0.05$ \\
& $800 \mathrm{mg} / \mathrm{kg}$ Bark & $16.85 \pm 2.10$ & $\mathrm{P}>0.05$ \\
& $400 \mathrm{mg} / \mathrm{kg}$ Root & $15.98 \pm 1.69$ & $\mathrm{P}>0.05$ \\
& $800 \mathrm{mg} / \mathrm{kg}$ Root & $19.00 \pm 2.44$ & $\mathrm{P}>0.05$ \\
& $20 \mathrm{mg} / \mathrm{kg}$ & $17.77 \pm 1.76$ & - \\
& Artesunate & $14.27 \pm 0.42$ & - \\
& Normal $($ control) & $14.12 \pm 0.51$ & $\mathrm{P}>0.05$ \\
& $400 \mathrm{mg} / \mathrm{kg}$ Leaf & $\mathrm{P}>0.05$ \\
& $800 \mathrm{mg} / \mathrm{kg}$ Leaf & $13.73 \pm 0.45$ & $\mathrm{P}>0.05$ \\
& $400 \mathrm{mg} / \mathrm{kg}$ Bark & $14.25 \pm 0.68$ & $\mathrm{P}<0.05$ \\
& $800 \mathrm{mg} / \mathrm{kg}$ Bark & $12.57 \pm 0.67$ & $\mathrm{P}>0.05$ \\
& $400 \mathrm{mg} / \mathrm{kg}$ Root & $13.90 \pm 0.34$ & $\mathrm{P}>0.05$ \\
& $800 \mathrm{mg} / \mathrm{kg}$ Root & $14.07 \pm 0.63$ & - \\
\hline & $20 \mathrm{mg} / \mathrm{kg}$ & $14.00 \pm 0.13$ & \\
& Artesunate & & \\
& & & \\
&
\end{tabular}

The results are expressed as mean \pm SEM, $\mathrm{P}>0.05$ is not significant, $\mathrm{n}=10$.

At respective doses of 10,100 and $1000 \mathrm{mg} / \mathrm{kg}$, as shown in tables ( $\mathrm{i}$,ii \& iii), all the three animals given the extracts of leaf, bark and root survived beyond the two weeks of observation without any sign of illness. When the extract was increased to 1600,2900 and 5000 all the animals equally survived. All the rats that received the doses $(10,100,1000$, 1600,2900 and $5000 \mathrm{mg} / \mathrm{kg}$ ) of the extract survived beyond the 2 weeks of observation. The medium lethal dose toxicity value $\left(\mathrm{LD}_{50}\right)$ of the extract must be above $5000 \mathrm{mg} / \mathrm{kg}$. There were no gross physical and behavioral changes including 
rigidity, sleep, diarrhea, depression, abnormal secretion, and hair erection within the observation period.

The mean WBC and HB (table iv) of the animal were $19.42 \pm 2.83$ and $14.27 \pm 0.42$ before the extract were given. When $400 \mathrm{mg} / \mathrm{kg}$ and $800 \mathrm{mg} / \mathrm{kg}$ doses of leaf extract were given the mean WBC and HB of the animal were $24.42 \pm 4.87$, $14.12 \pm 0.51$ and $19.13 \pm 4.18,13.73 \pm 0.45$ respectively. When $400 \mathrm{mg} / \mathrm{kg}$ of bark was given, WBC and $\mathrm{Hb}$ were $19.83 \pm 2.58$, $14.25 \pm 0.68$ and $16.85 \pm 2.10,12.57 \pm 0.674$ respectively. For $400 \mathrm{mg}$ and $800 \mathrm{mg} / \mathrm{kg}$ of root; the $\mathrm{WBC}$ and $\mathrm{Hb}$ were $15.98 \pm 1.69,13.90 \pm 2.34$ and $19.00 \pm 2.44,14.07 \pm 0.63$.

The WBC of the animal was high when $400 \mathrm{mg} / \mathrm{kg}$ of leaf was given and low when $400 \mathrm{mg} / \mathrm{kg}$ of root was given but the change in the WBC of all the test animal was not significant when compared to the normal.

$\mathrm{The} \mathrm{Hb}$ of the animals for all the extract doses dropped below normal but not statistically significant except for 800 $\mathrm{mg} / \mathrm{kg}$ of bark which was significant.

TABLE V: SHOWING THE EFFECT OF EXTRACTS OF A. congensis PARTS ON RBC AND PCV OF ALBINO RAT

\begin{tabular}{|c|c|c|c|}
\hline Parameters & Treatment & Mean values & Significance \\
\hline \multirow{8}{*}{$\begin{array}{c}\mathrm{RBC} \\
(\mathrm{x} 103 / \mu \mathrm{L})\end{array}$} & Normal (control) & $7.44 \pm 0.29$ & - \\
\hline & $400 \mathrm{mg} / \mathrm{kg}$ Leaf & $8.27 \pm 0.60$ & $\mathrm{P}>0.05$ \\
\hline & $800 \mathrm{mg} / \mathrm{kg}$ Leaf & $7.47 \pm 0.24$ & $\mathrm{P}>0.05$ \\
\hline & 400 mg/kg Bark & $7.77 \pm 0.28$ & $\mathrm{P}<0.05$ \\
\hline & $800 \mathrm{mg} / \mathrm{kg}$ Bark & $6.72 \pm 0.37$ & $\mathrm{P}>0.05$ \\
\hline & $400 \mathrm{mg} / \mathrm{kg}$ Root & $7.35 \pm 0.15$ & $\mathrm{P}>0.05$ \\
\hline & 800 mg/kg Root & $7.70 \pm 0.39$ & $\mathrm{P}>0.05$ \\
\hline & $\begin{array}{l}20 \mathrm{mg} / \mathrm{kg} \\
\text { Artesunate }\end{array}$ & $8.40 \pm 0.37$ & - \\
\hline \multirow[t]{8}{*}{ PCV (\%) } & Normal (control) & $47.95 \pm 0.83$ & - \\
\hline & $400 \mathrm{mg} / \mathrm{kg}$ Leaf & $45.63 \pm 1.02$ & $\mathrm{P}<0.05$ \\
\hline & $800 \mathrm{mg} / \mathrm{kg}$ Leaf & $41.92 \pm 1.43$ & $\mathrm{P}<0.05$ \\
\hline & 400 mg/kg Bark & $46.08 \pm 1.43$ & $\mathrm{P}<0.05$ \\
\hline & $800 \mathrm{mg} / \mathrm{kg}$ Bark & $40.50 \pm 1.05$ & $\mathrm{P}<0.05$ \\
\hline & 400 mg/kg Root & $42.22 \pm 1.17$ & $\mathrm{P}<0.05$ \\
\hline & $800 \mathrm{mg} / \mathrm{kg}$ Root & $44.02 \pm 1.42$ & $\mathrm{P}<0.05$ \\
\hline & $\begin{array}{l}20 \mathrm{mg} / \mathrm{kg} \\
\text { Artesunate }\end{array}$ & $42.97 \pm 0.85$ & - \\
\hline
\end{tabular}

The results are expressed as mean \pm SEM $\mathrm{P}<0.05$ is significant, $\mathrm{n}=10$.

TABLE VI: RESULTS SHOWING THE EFFECT OF EXTRACTS OF $A$. congensis PARTS ON MCV AND MCH OF TEST ANIMALS

\begin{tabular}{cccc}
\hline \hline Parameters & Treatment & Mean values & Significance \\
\hline \hline MCV (f/l) & Normal (control) & $64.55 \pm 2.15$ & - \\
& $400 \mathrm{mg} / \mathrm{kg}$ Leaf & $55.38 \pm 3.21$ & $\mathrm{P}<0.05$ \\
& $800 \mathrm{mg} / \mathrm{kg}$ Leaf & $56.17 \pm 3.09$ & $\mathrm{P}<0.05$ \\
& $400 \mathrm{mg} / \mathrm{kg}$ Bark & $59.40 \pm 2.59$ & $\mathrm{P}<0.05$ \\
& $800 \mathrm{mg} / \mathrm{kg}$ Bark & $60.50 \pm 4.52$ & $\mathrm{P}<0.05$ \\
& $400 \mathrm{mg} / \mathrm{kg}$ Root & $57.45 \pm 1.78$ & $\mathrm{P}<0.05$ \\
& $800 \mathrm{mg} / \mathrm{kg}$ Root & $57.28 \pm 3.41$ & $\mathrm{P}<0.05$ \\
& $20 \mathrm{mg} / \mathrm{kg}$ & $51.21 \pm 1.88$ & - \\
$\mathrm{ACH}$ (p/g) & Normal (control) & $19.21 \pm 0.84$ & \\
& $400 \mathrm{mg} / \mathrm{kg}$ Leaf & $17.19 \pm 1.92$ & $\mathrm{P}<0.05$ \\
& $800 \mathrm{mg} / \mathrm{kg}$ Leaf & $18.39 \pm 0.72$ & $\mathrm{P}>0.05$ \\
& $400 \mathrm{mg} / \mathrm{kg}$ Bark & $18.38 \pm 1.17$ & $\mathrm{P}>0.05$ \\
& $800 \mathrm{mg} / \mathrm{kg}$ Bark & $18.78 \pm 1.98$ & $\mathrm{P}>0.05$ \\
& $400 \mathrm{mg} / \mathrm{kg}$ Root & $18.92 \pm 0.51$ & $\mathrm{P}>0.05$ \\
& $800 \mathrm{mg} / \mathrm{kg}$ Root & $18.29 \pm 0.79$ & $\mathrm{P}>0.05$ \\
& $20 \mathrm{mg} / \mathrm{kg}$ & $16.70 \pm 0.80$ & \\
& Artesunate & & - \\
\hline \hline
\end{tabular}

The results are expressed as mean \pm SEM $\mathrm{P}>0.05$ is not significant, $\mathrm{n}=10$ $\mathrm{P}<0.05$ is significant

The RBC and PVC of the test animals (table $\mathrm{v}$ ) before the treatment were $7.44 \pm 0.29$ and $47.95 \pm 0.83$, when 400 and 800 $\mathrm{mg} / \mathrm{kg}$ of the leaf extract were given, the RBC and PVC of the animals were $8.27 \pm 0.60,45.63 \pm 1.02$ and $7.47 \pm 0.24$,
$41.92 \pm 1.43$ respectively. For 400 and $800 \mathrm{mg} / \mathrm{kg}$ of bark extracts, the RBC and PCV were $7.77 \pm 0.37,46.08 \pm 1.43$ and $6.72 \pm 0.37,40.50 \pm 1.05$ respectively. When 400 and 800 $\mathrm{mg} / \mathrm{kg}$ of root extracts were given, $\mathrm{RBC}$ and $\mathrm{PCV}$ were $7.35 \pm 0.15, \quad 42.02 \pm 1.17$ and $7.70 \pm 0.39, \quad 44.02 \pm 1.42$ respectively. The $\mathrm{RBC}$ of the animals were reduced significantly when $800 \mathrm{mg} / \mathrm{kg}$ of bark extracts was given. The PCV of all the animals were significantly reduced at all the doses of the extracts.

The results of the effect of extracts of leaf, bark and root of A. congensis on $\mathrm{MCV}$ and $\mathrm{MCH}$ of test animals were shown in Table VI. When $400 \mathrm{mg} / \mathrm{kg}$ and $800 \mathrm{mg} / \mathrm{kg}$ of leaf extract were given, the values for MCV and $\mathrm{MCH}$ were $55.38 \pm 3.21$, $17.19 \pm 1.92$, and $56.17 \pm 3.09,18.39 \pm 0.72$ respectively. For 400 and $800 \mathrm{mg} / \mathrm{kg}$ of bark, the values of MCV and $\mathrm{MCH}$ were $59.40 \pm 2.59,18.38 \pm 1.17$ and $60.50 \pm 4.52,18.78 \pm 1.98$, respectively.

The values at 400 and $800 \mathrm{mg} / \mathrm{kg}$ of root were $57.45 \pm 1.78$, $18.92 \pm 0.51$ and $57.28 \pm 3.41,18.29 \pm 0.79$ respectively. All the extracts significantly reduced the MCV of the tested animals but the $\mathrm{MCH}$ was significantly reduced when 400 $\mathrm{mg} / \mathrm{kg}$ of leaf extract was given.

TABLE VII: RESULTS SHOWING THE EFFECT OF EXTRACTS OF $A$. congensis PARTS ON MCHC AND PLATELET OF TEST ANIMALS

\begin{tabular}{|c|c|c|c|}
\hline Parameters & Treatment & Mean values & Significance \\
\hline \multirow[t]{8}{*}{$\mathrm{MCHC}(\mathrm{g} / \mathrm{dl})$} & Normal (control) & $29.76 \pm 0.92$ & - \\
\hline & $400 \mathrm{mg} / \mathrm{kg}$ Leaf & $30.96 \pm 1.73$ & $\mathrm{P}>0.05$ \\
\hline & $800 \mathrm{mg} / \mathrm{kg}$ Leaf & $32.78 \pm 0.96$ & $\mathrm{P}<0.05$ \\
\hline & 400 mg/kg Bark & $30.93 \pm 1.34$ & $P>0.05$ \\
\hline & $800 \mathrm{mg} / \mathrm{kg}$ Bark & $31.02 \pm 1.64$ & $\mathrm{P}>0.05$ \\
\hline & $400 \mathrm{mg} / \mathrm{kg}$ Root & $32.96 \pm 1.51$ & $\mathrm{P}<0.05$ \\
\hline & $800 \mathrm{mg} / \mathrm{kg}$ Root & $32.01 \pm 2.30$ & $\mathrm{P}<0.05$ \\
\hline & $\begin{array}{c}20 \mathrm{mg} / \mathrm{kg} \\
\text { Artesunate }\end{array}$ & $32.60 \pm 0.89$ & - \\
\hline \multirow[t]{8}{*}{ PLATELET } & Normal (control) & $728.33 \pm 8.31$ & - \\
\hline & $400 \mathrm{mg} / \mathrm{kg}$ Leaf & $\begin{array}{c}638.17 \pm \\
81.88\end{array}$ & $\mathrm{P}<0.05$ \\
\hline & $800 \mathrm{mg} / \mathrm{kg}$ Leaf & $\begin{array}{c}419.00 \pm \\
12.03\end{array}$ & $\mathrm{P}<0.05$ \\
\hline & 400 mg/kg Bark & $\begin{array}{c}635.50 \pm \\
23.31\end{array}$ & $\mathrm{P}<0.05$ \\
\hline & 800 mg/kg Bark & $\begin{array}{c}540.67 \pm \\
12.68\end{array}$ & $\mathrm{P}<0.05$ \\
\hline & 400 mg/kg Root & $\begin{array}{c}532.17 \pm \\
45.94\end{array}$ & $\mathrm{P}<0.05$ \\
\hline & 800 mg/kg Root & $615.33 \pm 4.13$ & $\mathrm{P}<0.05$ \\
\hline & $\begin{array}{c}20 \mathrm{mg} / \mathrm{kg} \\
\text { Artesunate }\end{array}$ & $684.50 \pm 14.24$ & - \\
\hline
\end{tabular}

The results are expressed as mean \pm SEM $\mathrm{P}<0.05$ is significant, $\mathrm{n}=10$.

The results of the effect of extracts of leaf, bark and root of A. congensis on $\mathrm{MCHC}$ and platelet of test animals were shown in Table VII. The MCHC and platelet of the test animals before the treatment were $29.76 \pm 0.92$ and $728.32 \pm 8.31$, respectively.

When $400 \mathrm{mg} / \mathrm{kg}$ and $800 \mathrm{mg} / \mathrm{kg}$ of leaf extracts were given, the values for MCHC and platelet were $30.96 \pm 1.73$, $638.17 \pm 81.88$ and $32.78 \pm 0.96,419.00 \pm 12.03$, respectively.

For $400 \mathrm{mg} / \mathrm{kg}$ and $800 \mathrm{mg} / \mathrm{kg}$ of bark, the values of MCHC and platelets were $30.93 \pm 1.34,635.50 \pm 23.31$ and $31.02 \pm 1.64$ and $540.67 \pm 12.68$, respectively.

The values at 400 and $800 \mathrm{mg} / \mathrm{kg}$ of root were $32.96 \pm 1.51$, $532.17 \pm 45.93$ and $32.01 \pm 2.30,615.33 \pm 4.13$ respectively. The extracts in all the doses significantly reduced the platelet of the test animals but the MCHC was significantly increased when $800 \mathrm{mg} / \mathrm{kg}$ of leaf, 400 and $800 \mathrm{mg} / \mathrm{kg}$ of root extracts 
were given.

\section{DISCUSSION}

Plants in general constitute a wide array of phytochemicals and when used in high dosages can elicit harmful effect on the body [10]. According to [11], A. congensis has frequently been used as antiplasmodial with great positive result but have been relatively uninvestigated for possible adverse effect on heamatology. Based on this, the study was conducted to investigate the adverse effect of $A$. congensis preparations on heamatological parameters of albino rat. In the acute toxicity study of the extract, no changes in the behavior was observed. All the mice that received the doses of the extracts survived beyond the 2 weeks of observation. This was in agreement with the study carried out by [12], in which the extract of $A$. congensis and $X$. aethiopica fruits showed no behavioral changes in mice treated with $20 \mathrm{mg} / \mathrm{kg}$ dose of the extract.

In this present study, $A$. congensis preparations reduced the PCV and RBC of the rat which also agrees with the work of [5]. The heamatological parameters of treated animals $(\mathrm{Hb}$, PCV) are index of anaemia. There was statistically significant difference in PCV of the treated animals from the control for all the doses of the extracts. The reduction in PCV and RBC may result to anaemia when used for long term.

Similarly, WBC which is an important index of pathological and physiological status [6], exhibited no significant difference, which implies that the presence of the phytochemicals which is for defense in plants, work in line with the WBC of the animals which is also for defense.

It would therefore be worthwhile to standardize the extract to know the dose and the time frame in order not to cause any adverse effect on the internal organs of the animals.

\section{CONCLUSION}

The high dose of the extracts should not be used for long time. The dosage range should not exceed 4 to 7 days to avoid any deleterious effect on the internal organ as well as cause anemia because of its effect on hematological parameters. The extract may be preferable for chronic infections where orthodox medicine failed.

\section{REFERENCES}

[1] Akerele O, Heywood V, Synge H. The conservation of medicinal plants. Cambridge University Press, Cambridge, UK. 1991.

[2] Rhiouani H, El-Hilaly J, Israili ZH, Lyoussi B. Acute and sub- chronic toxicity of an aqueous extract of the leaves of Hermiaria glabra in rodents. Journal of Ethnopharmacology. 2008; 118: 378-386.

[3] Verso ML. The Evolution of Blood Counting Techniques Read at a meeting of the Section of the History of Medicine, First Australian Medical Congress. 1962; 8: 149-58.

[4] Lamikanna AA, Brown D, Potocnik A, Casals-Pascual C, Langhorne J, Roberts DJ. Malaria anemia of mice and men. Blood. 2007; 110: 1828 .

[5] Iyawe HOT, Onigbinde AO. Impact of Plasmodium berghei and chloroquine on Haema antioxidant indices in mice. Asian Journal Biotechnology. 2009; 4: 30-35.

[6] Mengistie B, Makonnen E, Urga K. In vivo antimalarial activity of Dodonaea angustifolia seed extracts against Plasmodium berghei in mice model. MEJS. 2012; 4: 47-63.

[7] Tédong L, Dzeufiet PDD, Dimo T, Asongalem EA, Sokeng SN, Flejou $\mathrm{JF}$, et al. Acute and Subchronic toxicity of Anacardium occidentale
Linn (Anacardiaceae) leaves hexane extract in mice. African Journal of Traditional Alternative Medicine. 2007; 4(2): 140-147.

[8] Lorkes D. A new approach for acute toxicity testing. Arch Toxicolology. 1983; 54: 275-289.

[9] Jonsson M, Jestoi M, Nathanail AV, Kokkonen UM, Anttila M, Koivisto P, et al. Application of OECD Guideline 423 in assessing the acute oral toxicity oif moniliformin. Food Chem Toxicology. 2013; 53: 2732.

[10] Wang MW, Hao X, Chen K. Biological screening of natural products and drug innovation in China. Philosophical Transactions of the Royal Society Biological Sciences. 2007; 362, 1093-1105.

[11] Dike IP, Obembe OO. Towards the conservation of Nigeria's indigenous medicinal plants. Journal of Medicinal Plants Research. 2012; 6: 3517-3521.

[12] Ogbonnia S, Addekude AA, Bosa MK, Enwuru VN. Evaluation of acute and sub acute toxicity of A. congensis bark and xylopia aethiopica fruit mixtures used on the treatment of diabetes. African journal of Biotechnology. 2008; 7(6): 701-705. 